\title{
Raw Cow Milk Consumption and the Atopic March
}

\author{
Ton Baars ${ }^{1 \star t}$, Agnes Wold ${ }^{2}$, Dominique A. Vuitton ${ }^{3}$, Johan Garssen ${ }^{1,4}$ and \\ Anna Catharina Berge ${ }^{5 t}$
}

${ }^{1}$ Division of Pharmacology, Utrecht Institute for Pharmaceutical Sciences, Faculty of Science, Utrecht University, Utrecht, Netherlands, ${ }^{2}$ Department of Infectious Diseases, Institute of Biomedicine, Sahlgrenska Academy, University of Gothenburg, Gothenburg, Sweden, ${ }^{3}$ EA 3181, University Bourgogne Franche-Comté, Besançon, France, ${ }^{4}$ Danone Nutricia Research, Utrecht, Netherlands, ${ }^{5}$ Berge Veterinary Consulting BV, Vollezele, Belgium

Keywords: cow milk allergy, atopic march prevention, asthma, raw cow milk, risk-benefit

\section{INTRODUCTION}

The article "Dietary Prevention of Atopic March in Pediatric Subjects with Cow's Milk Allergy" in Frontiers of Pediatrics, 11 August 2020, reviews potential solutions to the current worldwide increase in cow's milk allergies. The authors state that "In the last years, diet is emerging as a relevant strategy to prevent allergic diseases through the active modulation of among others the immune system." We agree that there is an urgent need to find new dietary strategies to prevent food allergies as well as the allergic march. However, we feel that the authors of this review miss an important potentially preventive measure, namely raw, unpasteurized farm milk or more gently processed milk.

\section{OPEN ACCESS}

Edited by:

Enza D'Auria,

University of Milan, Italy

Reviewed by: Riccardo Castagnoli,

University of Pavia, Italy

*Correspondence:

Ton Baars

a.baars@uu.n

tThese authors have contributed equally to this work

Specialty section:

This article was submitted to

Pediatric Immunology,

a section of the journal

Frontiers in Pediatrics

Received: 04 October 2020 Accepted: 01 February 2021

Published: 18 February 2021

Citation:

Baars T, Wold A, Vuitton DA,

Garssen J and Berge AC (2021) Raw

Cow Milk Consumption and the Atopic

March. Front. Pediatr. 9:613906.

doi: 10.3389/fped.2021.613906

\section{RAW MILK IN EARLY CHILDHOOD}

There are review studies published about the role of raw milk in asthma and allergy (1-3). In more than $90 \%$ of epidemiological studies worldwide there was a protective effect of unprocessed cow's milk consumption on the development of asthma, hay fever and atopic sensitization in both in farm and urban children (1). The meta-analysis of Brick et al. (3) including 12 publications, show consistent protective outcomes of early and current raw milk consumption and asthma in both farm and non-farm children. Evidence was especially strong in the ALEX (4) and the PARSIFAL studies (5) in several regions of continental Europe. The study by Perkin and Strachan (6) in Shropshire, UK clearly demonstrated that raw farm milk was equally, or possibly more, effective in children from non-farming households than in farming children. On the other hand, farm children receiving shop milk or boiled farm milk have increased risk of asthma, allergies and atopy in contrast to those drinking raw farm milk (7).

The above studies have been criticized for their cross-sectional methodology, which may have included various types of biases. However, longitudinal observations of the children included in the European case-control cohort "PASTURE," from 2001 to present, combined with several complementary studies (e.g., the "GABRIELA" studies) supported that consumption of raw milk by the mother and/or the child actually protects against atopic allergy, and this is likely through an early modulation of the immune response $(2,8-10)$. Epidemiological studies have been evaluated in a meta-analysis and clearly indicate the protective effects of raw milk against asthma and allergies (3).

In addition to the potential tolerance-promoting effect of consumption of raw milk, there are indications that unpasteurized milk may be better tolerated than shop milk by cow's milk allergic children. In a small study eleven children with cow's milk allergy were tested in a double-blind provocation trial with either raw farm milk or pasteurized and homogenized "shop" milk (Table 1). Most children tolerated the maximum amount tested of raw milk $(50 \mathrm{ml})$, but far lower levels of 
shop milk ( $8.6 \mathrm{ml}$ on average; $P<0.01)(11)$. In the past 5 years, pre-clinical studies have analyzed various aspects of the raw milk protection against allergic reactions to explain the underlying effects of the protection against the atopic march in children (Table 1: 1).

The differences between raw farm milk and shop milk have been tested in sensitization and tolerance studies in mice (Table 1: 2; 3; 4). When increasing milk heating from 50 to $80^{\circ} \mathrm{C}$ was tested, it was shown that the allergic responses were present above $60^{\circ} \mathrm{C}$ in mice (Table 1: 5). Furthermore, in an asthmamouse model heated raw farm milk $\left(80^{\circ} \mathrm{C}\right)$ had a significant impact on the asthma parameters, whereas after raw milk consumption reactions were similar to those observed in the negative control mice (Table 1: 8 ). These preclinical mice studies indicate that the early life allergenic effects of commercial milk are primarily caused by heating of the heat-sensitive whey protein fraction and not by homogenization or fat standardization (13). This, however, does not preclude other additional factors, like the milk fat composition (n3, n6 FA) and of course more clinical validation is needed.

\section{CHANGES IN THE RAW MILK MATRIX}

The antigenic properties of raw milk may change after heat treatment. Beta-lactoglobulin (BLG), a protein which is not present in human milk, is considered to be the main allergen in cow's milk. In vitro studies showed aggregation and increased antigenicity of BLG when milk is heated above $60^{\circ} \mathrm{C}$ up to $90^{\circ} \mathrm{C}$, while heating above $90^{\circ} \mathrm{C}$ resulted in a decline of antigenicity, which is known as 'baked-milk' $(16,17)$. Other whey proteins are also reduced in concentration when milk is heated above $60^{\circ} \mathrm{C}$ (13). Hence, lower pasteurization temperatures and more gentle

TABLE 1 | Outcomes of pre-clinical studies in allergy and asthma (below) in coherence with a trial in children (above) (abbreviations explained at the bottom of the table).

\begin{tabular}{|c|c|c|c|c|c|}
\hline Test group human & Type of study & Milk comparison & Outcome symptoms & $\begin{array}{l}\text { Outcome } \\
\text { immunology }\end{array}$ & Publication \\
\hline $\begin{array}{l}\text { (1) Multiple allergic } \\
\text { children, } 1 \frac{1}{2} Y\end{array}$ & $\begin{array}{l}\text { DBPC Pilot study; } \\
\text { Tolerance }\end{array}$ & Raw, shop & $\begin{array}{l}\text { Better tolerance to Raw } \\
\text { milk: } 50 \text { vs. } 8.6 \mathrm{~mL} \text { of } \\
\text { Shop milk }\end{array}$ & No measurements & $\begin{array}{l}\text { Abbring et al. (11) in Clin Exp } \\
\text { Allergy. 2019, 00, 1-13; } \\
\text { doi: 10.1111/cea.13399 }\end{array}$ \\
\hline Test group mice & Type of study & Milk comparison & Outcome symptoms & $\begin{array}{l}\text { Outcome } \\
\text { immunology }\end{array}$ & Publication \\
\hline $\begin{array}{l}\text { (2) Female } \mathrm{C} 3 \mathrm{H} / \mathrm{HeOuj} \\
\text { mice, 3-5W }\end{array}$ & $\begin{array}{l}\text { Food allergy; } \\
\text { Tolerance }\end{array}$ & Raw, shop & $\begin{array}{l}\text { Raw milk: reduced } \\
\text { allergic symptoms (skin, } \\
\text { shock, temp) }\end{array}$ & No measurements & $\begin{array}{l}\text { Abbring et al. (12) in Nutrients } \\
2019,11,1721 ; \\
\text { doi: } 10.3390 / \text { nu11081721 }\end{array}$ \\
\hline $\begin{array}{l}\text { (3) Female } \mathrm{C} 3 \mathrm{H} / \mathrm{HeOuj} \\
\text { mice, 3-5W }\end{array}$ & $\begin{array}{l}\text { Food allergy; } \\
\text { Tolerance; } \\
\text { Epigenetics }\end{array}$ & Raw, shop & $\begin{array}{l}\text { Raw milk: reduced } \\
\text { allergic symptoms (skin, } \\
\text { shock, temp) }\end{array}$ & $\begin{array}{l}\text { Epigenetic histone } \\
\text { modifications }\end{array}$ & $\begin{array}{l}\text { Abbring et al. (12) in Nutrients } \\
2019,11,1721 ; \\
\text { doi: } 10.3390 / \text { nu11081721 }\end{array}$ \\
\hline $\begin{array}{l}\text { (4) Female } \mathrm{C} 3 \mathrm{H} / \mathrm{HeOuj} \\
\text { mice, } 4 \mathrm{~W}\end{array}$ & $\begin{array}{l}\text { Cow milk allergy; } \\
\text { Sensitization }\end{array}$ & $\begin{array}{l}\text { Raw, } 80^{\circ} \text {-heated, } \\
\text { Shop }\end{array}$ & $\begin{array}{l}\text { Raw milk: lower allergic } \\
\text { potential and less } \\
\text { symptoms (skin, shock, }\end{array}$ & $\begin{array}{l}\text { Lower lgE in Raw } \\
\text { milkmice; inhibition of } \\
\text { Th2 cytokines }\end{array}$ & $\begin{array}{l}\text { Abbring et al. (11) in Clin Exp } \\
\text { Allergy. 2019, 00, 1-13; } \\
\text { doi: 10.1111/cea.13399 }\end{array}$ \\
\hline
\end{tabular}

$\begin{array}{llll} & & & \\ \text { (5) Female } \mathrm{C} 3 \mathrm{H} / \mathrm{HeO} j & \text { Food allergy; } & \text { Raw; Steps from } & \text { Milk heated at } 65^{\circ} \mathrm{C} \text { and } \\ \text { mice, 3W } & \text { Tolerance } & 50^{\circ} \mathrm{C} \text { to } & \text { higher was no longer } \\ & 80^{\circ} \mathrm{C} \text {-heated } & \text { protective in terms of skin } \\ & \text { milk/30 min } & \text { response }\end{array}$

$\begin{array}{lll}\text { (6) Female } \mathrm{C} 3 \mathrm{H} / \mathrm{HeO} \text { je } & \text { Food allergy; } & \text { Raw, skimmed raw, } \\ \text { mice 3W } & \text { Tolerance } & \text { and pasteurized }\end{array}$

$\begin{array}{lll}\begin{array}{ll}\text { (7) Female } \mathrm{C} 3 \mathrm{H} / \mathrm{HeO} \text { je } \\ \text { mice 4W }\end{array} & \begin{array}{l}\text { Cow milk allergy; } \\ \text { Sensitization }\end{array} & \begin{array}{l}\text { Native Raw milk } \\ \text { whey and } \\ 80^{\circ} \mathrm{C} \text {-heated whey }\end{array} \\ \begin{array}{ll}\text { (8) Male BALB/c mice, } & \text { Asthma: House dust } \\ \text { 6-7W } & \text { Raw, } 80^{\circ} \mathrm{C} \text {-heated }\end{array} & \begin{array}{l}\text { Raw } \\ \text { mite allergy }\end{array}\end{array}$

Lower allergic potential and less symptoms (skin, shock, temp) after Raw and Skim Raw milk; higher risk after $78^{\circ} \mathrm{C}$-heated milk/15s.

Reduced allergic symptoms (skin, shock, temp) after Raw whey Improved lung function after Raw milk
Immunologically active whey proteins started a decrease in concentration at $60^{\circ} \mathrm{C}$; Immunoglobulins denaturation at $60 / 65^{\circ} \mathrm{C}$

No effects on SCFA in caecum; low lgE and Th2-related cytokines

Abbring et al. (14) in: Nutrients 2019, 11, 1499; doi: 10.3390/nu11071499
Abbring et al. (13) in Food \& Function, 11, 4982-93; doi: 10.1039/d0fo01175d

\section{Reduced Th2 cytokine response in the Raw whey group Reduced number of inflammatory cells}

\author{
Abbring et al. (11) in Clin Exp \\ Allergy. 2019, 00, 1-13; \\ doi: 10.1111/cea.13399 \\ Abbring et al. (15) in Front. \\ Immunol. 8, 1045.
} doi: 10.3389/fimmu.2017.01045 
treatment of milk may be a strategy to increase its tolerability in children with cow's milk allergies.

Further, experimental studies have shown that raw milk ameliorates the allergic reaction. Mice sensitized to house dust mite in an asthma model showed reduced airway responsiveness and eosinophil infiltration when fed raw milk, while heated raw milk did not have this effect (15). Furthermore, raw milk also down-regulated allergic symptoms to an unrelated allergen (ovalbumin) in a food allergy model (13). This implies that heat sensitive whey proteins play a role in tolerance development. Furthermore, the same group of researchers showed that differences in immunogenicity appeared already after heating of the milk to just above $60^{\circ} \mathrm{C}$ for $30 \mathrm{~min}$, which can be considered a milder treatment than the standard pasteurization procedure. Proteomic studies of heat-treated milk show decreased concentrations of several whey proteins which related to reduced tolerance in the mice model (13).

\section{REDUCING RAW MILK RISKS}

Naturally, there may be a risk that raw milk contains pathogens that may cause foodborne disease. Thanks to modern technologies and disease eradication and control programs in food producing animals, raw milk production can be carried out safely with closed milking systems and the maintenance of the cold chains. A review of outbreak data in USA associated with raw milk, reported by the Centers of Disease Control, indicates that such outbreaks have been reduced during the last decade, likely due to improved hygiene (18). Certain farmers specializing in producing raw milk for direct consumption may provide microbiologically safe raw milk by employing high hygienic standards. Berge and Baars (19) have provided evidence that various raw milk production systems exist that provide equal microbial safety as pasteurized milk. A sub-study revealed that the raw milk collected in the farms of the PASTURE study

\section{REFERENCES}

1. Braun-Fahrländer C, Von Mutius E. Can farm milk consumption prevent allergic diseases?. Clin Exp Allergy. (2011) 41:29-35. doi: 10.1111/j.1365-2222.2010.03665.x

2. Sozańska B. Raw cow's milk and its protective effect on allergies and asthma. Nutrients. (2019) 11:469. doi: 10.3390/nu11020469

3. Brick T, Hettinga K, Kirchner B, Pfaffl MW, Ege MJ. The beneficial effect of farm milk consumption on asthma, allergies, and infections: from metaanalysis of evidence to clinical trial. J Allergy Clin Immunol. (2020) 8:878-89. doi: 10.1016/j.jaip.2019.11.017

4. Riedler J, Braun-Fahrländer C, Eder W, Schreuer M, Waser M, Maisch S, ALEX, Study Team. Exposure to farming in early life and development of asthma and allergy: a cross-sectional survey. Lancet. (2001) 358:1129-33. doi: 10.1016/S0140-6736(01)06252-3

5. Waser M, Michels KB, Bieli C, Flöistrup H, Pershagen G, Von Mutius E, et al. Inverse association of farm milk consumption with asthma and allergy in rural and suburban populations across Europe. Clin Exp Allergy. (2007) 37:661-70. doi: 10.1111/j.1365-2222.2006.02640.x

6. Perkin MR, Strachan DP. Which aspects of the farming lifestyle explain the inverse association with childhood allergy? J Allergy Clin Immunol. (2006) 117:1374-81. doi: 10.1016/j.jaci.2006.03.008 participants had an endotoxin content lower than pasteurized and ultra-high temperature processed milk kept in non-farmer family fridges (20). Further, risk-benefit analyses are necessary for raw milk and raw milk products for different types of vulnerable consumers, based on the latest information of safe raw milk production.

\section{DISCUSSION}

Thus, as emphasized by Carrucci et al. (21), the costs for asthma and allergy are increasing. Evidence is accumulating that consumption of raw cow's milk might be an effective preventive strategy that should be further explored. Microbiological safety of such milk must be high priority and strictly controlled. In Western countries this commodity can be produced hygienically and delivered to consumers with existing cold chains to assure that the risk of infectious disease due to its consumption is very low (19). Future research is a must to unravel how safe milk derived products may be produced without damaging important immune modulators. Heating to kill pathogens should not be the only solution to produce microbiologically safe milk. New technological solutions for more gentle processing of milk and training raw milk producers in biosecurity and food hygienic procedures, may minimize the risk of contamination of raw milk by pathogens. In addition, raw milk intended for use in small children may easily be checked for the absence of significant pathogens by rapid PCR procedures before sale of the milk.

\section{AUTHOR CONTRIBUTIONS}

$\mathrm{TB}$ and $\mathrm{AB}$ designed and structured the article, wrote, and read the manuscript. All authors listed have made a substantial and intellectual contribution to the work and approved it for publication.
7. Loss G, Apprich S, Waser M, Kneifel W, Genuneit J, Büchele G, et al. The protective effect of farm milk consumption on childhood asthma and atopy: the GABRIELA study. J Allergy Clin Immunol. (2011) 128:766-73. doi: 10.1016/j.jaci.2011.07.048

8. Vuitton DA, Dalphin JC. From farming to engineering: the microbiota and allergic diseases. Engineering. (2017) 3:98-109. doi: 10.1016/J.ENG.2017.01.019

9. Lluis A, Depner M, Gaugler B, Saas P, Casaca VI, Raedler D, et al. Increased regulatory $\mathrm{T}$-cell numbers are associated with farm milk exposure and lower atopic sensitization and asthma in childhood. J Allergy Clin Immunol. (2014) 133:551-9. doi: 10.1016/j.jaci.2013.06.034

10. von Mutius E. Maternal farm exposure/ingestion of unpasteurized cow's milk and allergic disease. Curr Opin Gastroenterol. (2012) 28:570-6. doi: 10.1097/MOG.0b013e32835955d3

11. Abbring S, Kusche D, Roos TC, Diks MA, Hols G, Garssen J, et al. Milk processing increases the allergenicity of cow's milk-Preclinical evidence supported by a human proof-of-concept provocation pilot. Clin Exp Allergy. (2019) 49:1013-25. doi: 10.1111/cea.13399

12. Abbring S, Wolf J, Ayechu-Muruzabal V, Diks MA, Alashkar Alhamwe B, Alhamdan F, et al. Raw cow's milk reduces allergic symptoms in a murine model for food allergy - A potential role for epigenetic modifications. Nutrients. (2019) 11:1721. doi: 10.3390/nu11081721 
13. Abbring S, Xiong L, Diks MA, Baars T, Garssen J, Hettinga K, van Esch BC. Loss of allergy-protective capacity of raw cow's milk after heat treatment coincides with loss of immunologically active whey proteins. Food Function. (2020) 11:4982-93. doi: 10.1039/D0FO01175D

14. Abbring S, Ryan JT, Diks MA, Hols G, Garssen J, van Esch BC. Suppression of food allergic symptoms by raw cow's milk in mice is retained after skimming but abolished after heating the milk-A promising contribution of alkaline phosphatase. Nutrients. (2019) 11:1499. doi: 10.3390/nu110 71499

15. Abbring S, Verheijden KA, Diks MA, Leusink-Muis A, Hols G, Baars T, et al. Raw cow's milk prevents the development of airway inflammation in a murine house dust mite-induced asthma model. Front Immunol. (2017) 8:1045. doi: 10.3389/fimmu.2017.01045

16. Kleber $\mathrm{N}$, Krause I, Illgner S, Hinrichs J. The antigenic response of $\beta$ lactoglobulin is modulated by thermally induced aggregation. Eur Food Res Technol. (2004) 219:105-10. doi: 10.1007/s00217-004-0924-3

17. Bu G, Luo Y, Zheng Z, Zheng H. Effect of heat treatment on the antigenicity of bovine $\alpha$-lactalbumin and $\beta$-lactoglobulin in whey protein isolate. . Food Agric Immunol. (2009) 20:195-206. doi: 10.1080/09540100903026116

18. Whitehead J, Lake B. Recent trends in unpasteurized fluid milk outbreaks, legalization, and consumption in the United States. PLoS Curr. (2018) 10. doi: 10.1371/currents.outbreaks.bae5a0fd685616839c9cf857792730d1

19. Berge AC, Baars T. Raw milk producers with high levels of hygiene and safety. Epidemio Infect. (2020) 148:e14. doi: 10.1017/S0950268820000060
20. Gehring U, Spithoven J, Schmid S, Bitter S, Braun-Fahrländer C, Dalphin JC, et al. Endotoxin levels in cow's milk samples from farming and nonfarming families-the PASTURE study. Environ Int. (2008) 34:1132-6. doi: 10.1016/j.envint.2008.04.003

21. Carucci L, Nocerino R, Paparo L, Di Scala C, Berni Canani R. Dietary prevention of atopic march in pediatric subjects with cow's milk allergy. Front Pediatrics. (2020) 8:440. doi: 10.3389/fped.2020.00440

Conflict of Interest: $\mathrm{AB}$ was employed by the company Berge Veterinary Consulting BV, as independent consultants $\mathrm{AB}$ and $\mathrm{TB}$ perform limited paid consulting on dairy farms and presentations at workshops for raw milk producers. JG is partly employed at Danone Nutricia Research.

The remaining authors declare that the research was conducted in the absence of any commercial or financial relationships that could be construed as a potential conflict of interest.

Copyright (C) 2021 Baars, Wold, Vuitton, Garssen and Berge. This is an open-access article distributed under the terms of the Creative Commons Attribution License (CC $B Y)$. The use, distribution or reproduction in other forums is permitted, provided the original author(s) and the copyright owner(s) are credited and that the original publication in this journal is cited, in accordance with accepted academic practice. No use, distribution or reproduction is permitted which does not comply with these terms. 